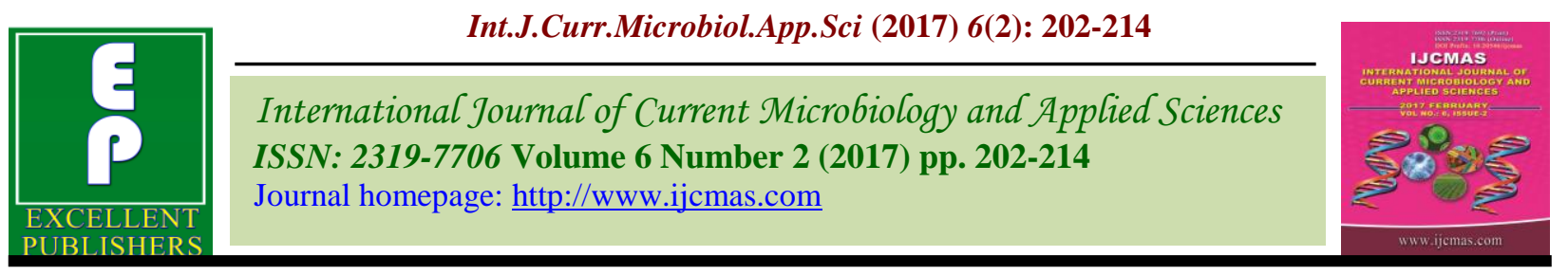

Original Research Article http://dx.doi.org/10.20546/ijcmas.2017.602.027

\title{
Morpho-Physiological Traits of Different Rice Varieties Grown Under Water Logged and Submerged Condition
}

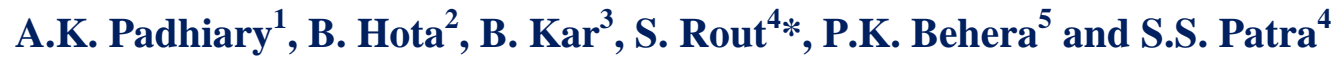 \\ ${ }^{1}$ Krishi Vigyan Kendra, RRTTS Campus, Chiplima, Sambalpur- 768026 (OUAT), Odisha, India \\ ${ }^{2}$ Department of Plant Physiology, College of Agriculture, OUAT, \\ Bhubaneswar-751003, Odisha, India \\ ${ }^{3}$ Department of Seed Science and Technology, College of Agriculture, OUAT, \\ Bhubaneswar-751003, Odisha, India \\ ${ }^{4}$ School of Forestry and Environment, Sam Higginbottom University of Agriculture Technology \\ and Sciences, Allahabad-211007, Uttar Pradesh, India \\ ${ }^{5}$ Department of Agronomy, College of Agriculture, OUAT, Bhubaneswar-751003, Odisha, India \\ *Corresponding author
}

A B S T R A C T

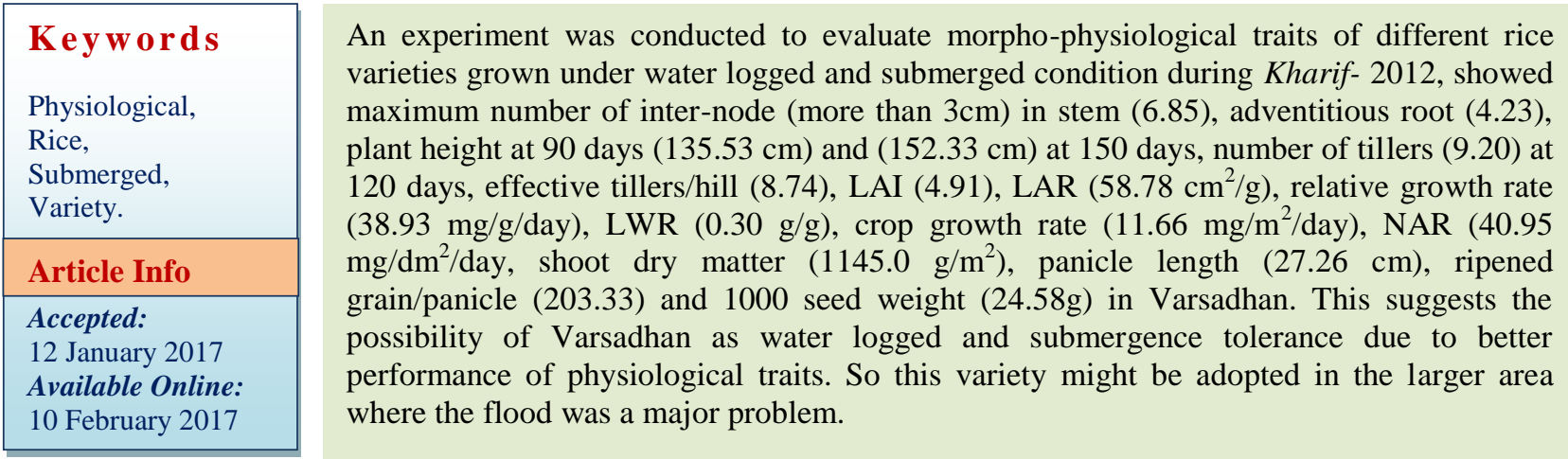

\section{Introduction}

Rice is one of the most important cereal crop, widely cultivated in a varied diverse ecosystem. It consists 23 percent of global cereal acreage. India is one of the world's largest producers of rice next to China. In Odisha, around $93 \%$ area is covered with rice crop during kharif season which is generally sown in June-July and harvested in November-December. In eastern India about 10 million hectares of area is covered with the Water logged area where the yield of rice is only 2.4 tons/ha. It meets about 31 and 17 percent of total calories and protein requirement respectively. Hence it is considered as a staple food of $65 \%$ of Indian population. Rice production in India is an important part of the national economy. In India lowland rice area is about 14.4 million hectare which accounts for $32.4 \%$ of the total area of the rice crop in the country. The submerged rice ecosystem in India, represents $26 \%$ of total cultivated. Considering the rising 
population growth in India the expected rice requirement must be augmented to a level of 130 million tons by 2050, Paroda (2006) informed that, rice production in India is almost stagnant for last six years. Hence, to achieve the targeted yield under reduced area, declining impact use efficiency having limited irrigation facility in rainfed ecosystem the appropriate varieties should be used in the lowland. The genetic yield potential of crop varieties is limited by the environment, including abiotic and biotic stresses (Oreke et al., 1999). Among the abiotic stresses mainly water logging, light and temperature, soil salinity and drought may adversely affect plant growth and performance (Dalmia and Sawhney, 2004). So the plant breeder in collaboration with physiologist and other sister disciplines should evaluate suitably improved rice varieties with better yield potential having tolerant capacity in deepwater areas which is one of the critical needs for suitable rice production in deep water logged ecology and it will overcome a major problem for the farming community of the state. Deep water rice is defined as rice that is flooded deeper than $15 \mathrm{~cm}$ for one month or longer during the growing season (Cateling, 1985) with turn flooding that growing in the very deeply flooded areas. In Odisha flooding usually, occurs in 3 stages of plant growth and can last for seven days to one month. The stipulation that flooding must be sustends for at least one month is to be distinguished deep water rice area from other flood prone areas. In the coastal belt, the water may rise up to more than $50 \mathrm{~cm}$ by tide action and the flash flood areas where rice may be temporarily submerged for only a few days. Most deep water rice survives by elongation of the stem, where as other rice type lack these characteristics and are destroyed by deep water. The rise in water is the most important source of flooding. Monsoon rain in the water shed brings the river down in foot flood. On reaching the flat topography the flow rate slow and over bank spills of turbid silty water bring to flood the land. Rice grown in more than 50 $\mathrm{cm}$ water for one month or longer period during the cropping season is called deepwater rice. They are of two types such as "traditional tall and floating". Traditional tall varieties are tall with long leaves and grown in water depth in between $50-100 \mathrm{~cm}$ where as floating rice is grown in $100 \mathrm{~cm}$ or deeper situation. In the coastal belt of Odisha rice grown in low lying areas during monsoon are called deepwater rice. The deep water rice grown in Asian and African countries are of different types. The growth of deep water rice varieties largely depends upon factors such as flooding region, micro relief and soil type etc. It has been noted that in Asia 6000 rice cultivars are grown but in Bangladesh 2000 deepwater rice is found. Almost all the deepwater cultivar is strongly photo period sensitive. Photosensitivity fixes flowering time at a favourable point in the flooding period, enables the plant to escape the adverse effect of low temperature in the reproductive phase, and usually ensure crop maturity as soon as flood has receded. The panicle is often waned; spreading type and seeds are prone to scatter.

Seeds have dormancy period lasting for several weeks. Deep water (floating rice) rice has three special adaptations which are as follows: 1) Ability to elongate with the rise of water level. 2) Develop nodal tillers and roots from upper node in the water. 3) Upward bending of the terminal part of the plant, which is called "kneeing" that keeps the reproductive part above the water, are the flood subside. During water logging submerged plant are exposed to the reduction in $\mathrm{O}_{2}$ supply because of the slow diffusion rate of $\mathrm{O}_{2}$ in water and its limited solubility. Turbid flood water can become anaerobic, especially during the night. Growth is greatly inhibited in the deficiency (hypoxia) or complete absence (anoxia) of oxygen. The water logging situation is rain fall submerge 
for about 3 months (July-September) under water depth varying from 0.5 to $2 \mathrm{~m}$. At the end rainy of season when the drainage channels become empty the accumulated surface water start to receive and the land become dry from December onwards. In water logged area farmers grow only rice during the rainy season under rainfed condition. But success of obtaining profitable crop demand on distribution of monsoon rain, time and depth of flooding and water logging, too much of water logging also makes the field unsuitable to grow any crop other than rice in rainy season. Prolong water logging during the rainy season for the most part of crop growth reduces tillering and growth of the normal rice crop. Erratic or early heavy rain fall results in sudden water logging in rice field and submerges the crop in early seedling stage. The crop is damaged completely if the situation occurs an early vegetative period. Perfect evaluation of improved rice varieties with better yield potential in deep water areas is one of the critical needs for sustainable rice production in deep water logged ecology. Rice cultivar also varies in their capacity to tolerate water logged and submergence (Perata and Voesenek, 2007). Because of these above facts, the present experiment was planned and conducted in the Adaptive Research Station, Sakhigopal, Puri during the wet season of 2012 with the following objectives to study the Morpho-physiological traits of different rice varieties grown under water logged and submerged condition.

\section{Materials and Methods}

The field experiments on rice were conducted during kharif 2012 in Adaptive Research Station, Sakhigopal, Puri to study the Morpho-physiological traits of different rice varieties grown under water logged and submerged condition. The soil of experimental field of Sakhigopal farm is clay loam, texture slight acidic in nature. The
Adaptive Research Station, Sakhigopal is situated in $19^{\circ} 48^{\prime}$ North Latitude and $85^{\circ} 52^{\prime}$ East Longitude and $20 \mathrm{Km}$ away from the Bay of Bengal with an altitude of $6 \mathrm{~m}$ above the mean sea level. The climate is relatively warm and humid in nature with short mild winter. The average annual rainfall of Sakhigopal is $1408.8 \mathrm{~mm}$ which is received from South-West monsoon during 2012. Rice varieties taken as treatments are-1) Sarala, 2) Hanseswari, 3) Varshadhan, 4) Bankoi, 5) Champa, 6) CR-925-2. The seeds were procured from the Adaptive Research Station, Sakhigopal, Puri for the experiment. The date of sowing in the nursery bed was conducted from $7^{\text {th }}$ June 2012. The nursery bed was developed for planting of six varieties of rice as mentioned above. The required amount of FYM and phosphatic fertilizers were well mixed with the soils of nursery for development of fertility of soil, before date of sowing. The six varieties were sown by in lines with keeping appropriate spacing between the varieties. The irrigation channels were kept surrounding the seed beds. Frequent sprinkler irrigation was given for seedbed initially and after germination irrigation management was done in such a manner that the raised seed bed remained moistened without any standing water over its surface for one week. Thereafter standing water was maintained up to $3 \mathrm{cms}$. For the better growth of seedlings, minimum $\mathrm{N}$ fertilizer was given in seed bed. Before seven days of rooting of seedling granular pesticide as per as recommendation was applied in seed bed in order to avoid the infection of disease and pest after the transplanting. After 21 days of sowing the seedling was up rooted for transplanting on 05 July 2012. The main land $(50 \mathrm{~m} \times 40 \mathrm{~m})$ was ploughed with tractor after harvest of the previous crop. Then FYM at $5 \mathrm{t} / \mathrm{ha}$ was spread over the field. Again the field was cross-ploughed and levelled properly. Two days prior to transplanting for each sowing the irrigation was given to a plot 
size of 400 sq.m (50m x $8 \mathrm{~m}$ ) for puddling by the power tiller and a little standing water was maintained in the field. Further, main plot $(50 \mathrm{~m} \times 8 \mathrm{~m})$ was divided into three stripes representing three replications. Before transplanting of seedlings and basal dose of the $15 \mathrm{Kgn}, 30 \mathrm{Kg}_{2} \mathrm{O}_{5}$ and $30 \mathrm{Kg} \mathrm{K}_{2} \mathrm{O}$ per hectare were applied and mixed thoroughly in soil during puddling. Rest nitrogen was top dressed twice. The first top dressing of nitrogen at $30 \mathrm{Kg} / \mathrm{ha}$ in the form of Urea was applied after 15 days of transplanting. The second top dressing of nitrogen at $15 \mathrm{~kg} / \mathrm{ha}$ in the form of Urea was applied at 112 days after transplanting. Twenty one days of old seedlings of rice varieties were transplanted with a spacing of $20 \mathrm{~cm} \times 10 \mathrm{~cm}$ having two seedlings per hill. Hand weeding was done at 15 days and 35 days after transplanting. Due to water logged condition the weed population was minimum and suppressed. To control the insect and pests thaiman granule at $10 \mathrm{~kg} / \mathrm{ha}$ was applied along with the first top dressing of nitrogen. After receding of submergence stem borer attack was observed and monocrotopus 1 1/ha were applied. Crop was harvested on $05^{\text {th }}$ December 2012 after it attains physiological maturity. The observations were recorded on five randomly selected competitive plants in each replication for all the characters and tagged for recording a representative sample of the entire population. The data were recorded for following traits: Pre-harvest observations i.e., Plant height $(\mathrm{cm})$, Leaf Area Index, Leaf Weight Ratio, Specific Leaf Area, Specific Leaf Weight, Leaf Area Duration, Leaf area ratio was calculated using formula of Watson, (1958), Crop growth rate (CGR) was calculated by using formula of Brown, (1984), Net assimilation rate (NAR), Leaf area duration, Number of tillers/hill, Number of effective tillers/hill at 90 days/150 days and post harvest observation i.e., shoot dry matter and its partitioning at successive growth stages, Number of spike lets/panicle, Number of matured grains/panicle, Sterility percentage at maturity, 1000 seed weight, Grain yield $\left(\mathrm{g} / \mathrm{m}^{2}\right)$, Shoot bio-mass above ground level $\left(\mathrm{g} / \mathrm{m}^{2}\right)$ and its partitioning into leaf, stem and panicle were recorded and Harvesting Index (HI) were calculated. The experimental design adopted for this research work was simple randomized block design (RBD). The pre- and post-harvest observations were statically analyzed following the RBD as out lined by Panse and Sukhatme (1961).

\section{Results and Discussion}

The present experiment was conducted during kharif, 2012 in an RBD design comprising of six rice varieties in Adoptive Research Station, Sakhigopal, Puri to screen out the tolerant rice varieties under water logged and submerged condition. The various morphophysiological characters recorded of rice varieties and analyzed. Data presented in the table 1 indicated that the number of inter nodes (more than $3 \mathrm{~cm}$ length) present in the stem was maximum in Varshadhan (6.85) followed by Hanseswari (6.61) whereas the minimum value of the same was exhibited by Champa (4.10) which was at par with Bankoi (4.12) under submerged condition. A significant difference was found within the varieties except Bankoi, Champa and CR925-2.Wide variation among the varieties was recorded in respect to above character as per the C.V. value. Maximum number of nodes with adventitious roots were exhibited by Varshadhan (4.23) which was significantly higher among the varieties. On the other hand Champa showed minimum (2.93) followed by Bankoi (2.98) in response to submerged condition. Survival percentage was maximum in Varsadhan (71.33) and minimum was recorded in Bankoi (54.27). Plant height recorded at 90 days (before submergence) indicated that highest value was exhibited by Varsadhan (135.53 cm) followed by Hansewari $(132.56 \mathrm{~cm})$ whereas lowest value 
of the same was showed by Champa $(108.06 \mathrm{~cm})$. The plant height recorded after the submergence (at 150 days) indicated that Varsadhan exhibited highest value $(152.33 \mathrm{~cm})$ followed by Hanseswari $(150.80 \mathrm{~cm})$ with an increase of $12.4 \%$ and $13.75 \%$ respectively whereas the minimum plant height was recorded in Champa (135.07 $\mathrm{cm}$ ) having $25 \%$ increase from the former(at 90 days) (Table 2). On whole the increase of plant height after the submergence varied from $12.4 \%$ to $26 \%$ as compared to before submergence. From the table 2 it was revealed that the number of tillers recorded at 90 days after water logged (water depth 53 $\mathrm{cm}$ ) indicated that maximum tillering was exhibited by Hanseswari (9.53/hill), followed by Varsadhan $(9.50 /$ hill), whereas the lowest number of tillers were recorded from Bankoi (8.82). The number of tillers recorded at 120 days after water logged (at water depth 70 $\mathrm{cm}$ ) indicated that maximum tiller was exhibited by Varsadhan (9.20) followed by Hanseswari (9.10) whereas lowest value of the same was recorded from Bankoi (8.03) followed by Champa (8.20). The reduction of number of tillers ranged from $3.15 \%$ in Varsadhan to $8.95 \%$ in Bankoi in response to water logged situation. As regards to effective tillers per hill it was found that maximum value was recorded in Varsadhan (8.74) with $95 \%$ effectiveness whereas in Bankoi recorded $82.5 \%$ (6.68) after the submergence (Table 2). Significant difference in percentage of effective tillers as well as number of tillers per plant among the varieties was noted. Elongation ability is an escape mechanism from partial or total submergence. Submergence enhanced the elongation of the shoots of all the cultivars though the increase of shoot length is greater in the susceptible genotypes, ranging from $19 \%$ to $26 \%$ where as the height of the submergence-tolerant cultivar increased only by $12.4 \%$ to $13.75 \%$ (Table 2). From the present experiment it was found that. Varsadhan and Hanseswari showed greater shoot elongation than other cultivars under submerged condition with reduced elongation rate under submerged condition for better survival. It was also found that elongation of internode (more than $3 \mathrm{~cm}$ length) was maximum with Varsadhan (6.85) followed by Hanseswari (6.61) whereas on minimum with Bankoi (4.12) (Table.2). Internode elongation started from 90 days after transplanting up to 150 Days after planting (DAP) which is most important mechanism for increasing plant height in very deep water for better survival. It was thought elongation of internodes was considered to be due to increase the number of cells (Sugawara and Horikawa, 1971) and lengthening of cells (Nasiruddin et al., 1977). Besides this increase of height of the plant was due to accumulation of ethylene in the plant cells under submerged condition which led tenfold increase of cells in the zones which are evident from the recent revealing. The tillers that were developed after the submergence do not contribute grain yield. The non tolerant rice genotypes as compared to tolerant variety, the percentage of effective tillers were less because there was damage of tillers due to anoxia stage under submergence condition and energy required for survival was very less.

From the table 3 it was revealed that among the varieties Varshadhan exhibited at the same maximum LAI (4.91) followed by Hanseswari (4.75), whereas the lowest value (3.32) was showed in Bankoi. However significant difference was found within the varieties. From the $\mathrm{CV}$ Value it was found that wide variation among the varieties in regards to LAI exists. But in case of SLA reverse trend was reflected. Under water logged condition SLA was found to be maximum in case of Bankoi $\left(212.74 \mathrm{~cm}^{2} / \mathrm{g}\right.$ ) followed by Champa $\left(182.42 \mathrm{~cm}^{2} / \mathrm{g}\right)$ and CR$925-2\left(176.39 \mathrm{~cm}^{2} / \mathrm{g}\right)$ (Table 3$)$. The minimum value of the same was recorded in 
Varshadhan $\left(139.61 \mathrm{~cm}^{2} / \mathrm{g}\right)$. From the table 3 it was revealed that maximum specific leaf weight (SLW) was recorded in Bankoi (4.48 $\left.\mathrm{mg} / \mathrm{cm}^{2}\right)$ followed by Champa $\left(4.40 \mathrm{mg} / \mathrm{cm}^{2}\right)$. On the contrary the minimum value of SLW was exhibited by Varshadhan $\left(3.89 \mathrm{mg} / \mathrm{cm}^{2}\right)$. Significant difference among the varieties was noted. In case of leaf area ratio (LAR) it was noted that at flowering stage of different varieties was significantly influenced by submerged condition. Varsadhan recorded the highest LAR $\left(58.78 \mathrm{~cm}^{2} / \mathrm{g}\right)$ followed by Hanseswari $\left(56.96 \mathrm{~cm}^{2} / \mathrm{g}\right)$ but Bankoi exhibited lowest value $\left(43.35 \mathrm{~cm}^{2} / \mathrm{g}\right.$ ) (Table 4). There was significant difference was found among the varieties. From the table 4 it was revealed that the relative growth rate (RGR) of the varieties varied from 32.40 to $38.93 \mathrm{mg} / \mathrm{g} /$ day. The highest RGR (38.93 $\mathrm{mg} / \mathrm{g} /$ day) was recorded in Varsadhan followed by Hanseswari (37.36 $\mathrm{mg} / \mathrm{g} /$ day) and Sarala $(37.33 \mathrm{mg} / \mathrm{g} /$ day $)$ whereas the minimum value of the same was recorded in Bankoi (32.40mg/g/day). Among the treatments significant difference was noted. From the data presented in table 4 LWR was affected by submergence. Like LAR there was significant difference among the varieties Varsadhan contributed the highest LWR ( 0.30 $\mathrm{g} / \mathrm{g})$ followed by Hanseswari $(0.27 \mathrm{~g} / \mathrm{g})$ whereas the lowest LWR $(0.22 \mathrm{~g} / \mathrm{g})$ was showed in Bankoi. Significant difference among the varieties was observed.

The crop growth rate (CGR) of the varieties showed that the maximum value (11.66 $\mathrm{mg} / \mathrm{m}^{2} /$ day) was showed in case of Varsadhan whereas the minimum value of the same was recorded in Bankoi $\left(8.15 \mathrm{mg} / \mathrm{m}^{2} /\right.$ day $)$. Significant difference was found among the varieties (Table 5). Comparison between the varieties as regards to NAR activities it was revealed from the data presented in table 5 that Varsadhan exhibited maximum value (40.95 mg/dm $2 /$ day) followed by Hanseswari (39.77 $\left.\mathrm{mg} / \mathrm{dm}^{2} / \mathrm{day}\right)$. On the other hand minimum value of the same was showed by
Bankoi (34.40 mg/ $\mathrm{dm}^{2} /$ day). There is no wide variation in NAR activities among the varieties as per the C.V. value. Significant difference was recorded among varieties. Variation in leaf Area duration (LAD) among the tested varieties estimated from heading to maturity is reflected in table 5. It was revealed from the data that the maximum LAD was exhibited by Varsadhan (131.70 days) followed by Hanseswari (128.30 days) whereas minimum value of the same was recorded with Bankoi (114.50days) which is $13.05 \%$ less than the former one. Among the varieties significant difference was recorded with lesser variation.

Rice plant is composed of leaves that are physiological different in age and activity. For emergence of a leaf rice plant takes initially 4 to 5 days but afterwards it takes 7-8 days before the initiation of panicle (Yoshida, 1981). So a rice crop can attain maximum LAI values of 10 at heading. However, the critical LAI value at maximum crop photosynthesis is about 6-7 under normal climate / weather conditions. Due to submergence it was tended to decrease significantly and registered maximum LAI. It was ascertained that before the submergence the crop had greater leaf area and it was efficient to intercept light as well as to produce biomass after the submergence (Ghosh, 2000). Among the varieties the maximum LAI was contributed by Varshdhan (4.01) after the submergence where in the same value was maximum in case of Hanseswari (9.81) before the submergences.

Specific leaf weight (SLW) and leaf area ratio (LAR) decreased due to submergence. After the submergence, many scientists reports that NAR is positively associated with SLW and negatively with LAR. Therefore SLW is considered as a useful tool for selection of genotypes for higher NAR-rice varieties at the vegetative growth stage under stress prone 
environments (Chatha and Khan, 1991; Murty and Pattanaik, 1986).

Leaf area duration (LAD) expresses the magnitude and persistence of leaf area or leafiness during the period of crop growth. It reflects or seasonal integral of light interception which has highly correlate with yield. It is because biomass duration (BMD) is analogous to LAD of which LAI/Leaf area is determinant. It has been discussed earlier that submergence tremendously affects leaf area and its ancillary character. Regardless the varieties in submergence reduced LAD and LWR (leaf weight ratio) as compared to before submergence. The tolerant varieties have higher LAD and LWR than other varieties. In respect to these two parameters the sequence followed as stated below. Varsadhan > Hanseswari > Sarala > CR-925$2>$ Champa $>$ Bankoi.

In case of shoot dry matter content of plant and its parts at harvest differ significantly among the varieties (Table 6). It was found that after the submergence highest shoot- dry matter (DM) was exhibited by Varsadhan $\left(1145.0 \mathrm{~g} / \mathrm{m}^{2}\right)$ followed by Hanseswari $\left(1122.3 \mathrm{~g} / \mathrm{m}^{2}\right)$ whereas the minimum value of the same was showed in Bankoi $\left(925.3 \mathrm{~g} / \mathrm{m}^{2}\right)$. As regards to mean dry matter contribution of the plant parts it was noted that highest dry matter contribution was exhibited by panicle $(51.6 \%)$ followed by stem $(35.7 \%)$ and similar trend was also exhibited by the individual varieties as regard to partition of plant parts to shoot dry matter. Among the varieties the highest stem and leaf dry matter was contributed by Varshadhan to shoot dry matter but panicle dry matter contribution was maximum in Hanseswari.

The present study revealed that the total dry matter production was maximum in tolerant cultivar Varsadhan $\left(1145.0 \mathrm{~g} / \mathrm{m}^{2}\right)$ followed by Hanseswari $\left(1122.3 \mathrm{~g} / \mathrm{m}^{2}\right)$ where as minimum value of the same was showed by Bankoi $\left(973.3 \mathrm{~g} / \mathrm{m}^{2}\right)$ which was $23.74 \%$ reduction is comparison to Varshadhan at after submergence. Sarkar et al. (2006) explained that cultivars having higher dry mass can withstand submergence and have better regeneration capacity as well as faster growth after submergence to produce sufficient biomass in a shorter period which coincides the findings of present experiment.

Dry matter accumulation Varsadhan followed Hanseswari which enabled the plant to withstand under submerged condition. This helped better generation capacity as well as faster growth after the submergence to produce sufficient biomass in a shorter period. Perhaps the production of biomass was possible due to more photosynthesis occurred by the plant parts above the water level.

Maximum panicle length $(27.26 \mathrm{~cm})$ was exhibited by Varshadhan followed by Hanseswari $(25.83 \mathrm{~cm})$, whereas Bankoi showed the lowest value $(24.80 \mathrm{~cm})$ followed by Sarala $(24.90 \mathrm{~cm})$. Significant difference among the varieties was exhibited. A maximum number of grains per panicle were contributed by the variety Varsadhan (232.33) followed by Hanseswari (225.96) whereas Champa exhibited lower value (187.15) of the same. There was significant difference among the varieties (Table 7). Among the cultivars ripened grains per panicle was highest in Varsadhan (203.33) which was significantly greater than other varieties (Table 7). On the contrary, Champa and Bankoi had significantly lower values of the same than other genotypes. When the ripened grains expressed as the percentage of the total grains per panicle, it revealed that Varsadhan had $(91.56 \%)$ significantly higher value of the same than other varieties.

From the table 7 it was indicated that the number of chaffy grains per panicle was highest with variety Hanseswari (42.66) but the lower value was noted with Varsadhan 
(17.00). The highest percentage of chaffy grain per panicle was observed in Bankoi $(18.76 \%)$ whereas the percent of chaffy grain per panicle was minimum with Varsadhan $(8.33 \%)$.

From the data reflected in table 8 on 1000 seed weight of different varieties indicated that maximum test weight of the grain was showed by Varshadhan (24.58 g) followed by Bankoi (23.27 g) whereas minimum seed weight was exhibited by CR-925-2(18.20 g). It was found that test weight is poorly positively correlated with grain yield. Data presented in table 8 revealed that under submerged condition Varsadhan contributed highest yield (41.73q/ha) followed by Hanseswari $(41.53 \mathrm{q} / \mathrm{ha})$ but the minimum grain yield was contributed by Bankoi (28.70q/ha) followed by Champa (29.76q/ha). The percentage of reduction in respect to yield from the highest to lowest is $31.22 \%$ statistically significant differences were noted among the varieties in respect to yield. Data presented in table 8 indicated that harvest index (HI) ranged from $27.76 \%$ to $36.97 \%$ among the varieties under submerged condition. The highest value of $\mathrm{HI}$ was showed in Varshadhan (36.97\%) followed by Hanseswari (36.24\%) whereas minimum value of the same was exhibited by Bankoi $(27.76 \%)$ with reduction of $24.9 \%$ from the former.

Comparison of grain yield between cultivars of rice revealed that there was wide variation in grain yield among the varieties ranging from $28.70 \mathrm{q} / \mathrm{ha}$ in Bankoi to $41.73 \mathrm{q} / \mathrm{ha}$ in Varsadhan (Table 8) under submerged condition. On the whole, grain yield of all the genotypes remained in the following sequence. Varsadhan $>$ Hanseswari $>$ Sarala $>$ CR 925-2 > Champa > Bankoi. Yield components that influence grain yield of a cultivar under submerged condition are (a) 1000 grain weight (b) Number of panicles/unit land area, (c) number of ripened grains /panicle out of which the last two parameters determine the grain yield of a variety under submerged condition. In the present study, higher grain yield obtained in Varsadhan due to more number of panicles (effective tillers /hill) per hill which indicates survival percentage under submerged condition and more grains /panicle.

Similarly number of effective tillers /hill was highest (9.06/hill) in Varsadhan followed by Hanseswari (8.70/hill) where as lowest value was exhibited by Bankoi (6.86/hill) which indicates the survival percentage of the variety under submerged condition. Under submerged condition the hydrolyzed products of the sucrose by invertase are compensated as respiratory substrate for the sink tissue (panicles) rather than conversion of grain filling materials like starch (Fridman and Zamir, 2003). There is greater ability of the sink tissues to store sugar (Chen and Wang 2008). Among the yield components effective tiller are very important because the final yield mainly function of the number of panicle bearing tiller (Baloch et al., 2006). The data presented in experimental findings indicated that the highest yielder Varsadhan (41.73 q/ha) had highest effective tillers (9.06/hill) where as the minimum number of effective tillers was contributed by Bankoi (6.86/hill) having yield of $28.70 \mathrm{q} / \mathrm{ha}$. Varietal difference in respect of effective / productive tillers had their positive correlation with rice grain yield has already documented and reviewed earlier (Baruah et al., 2006; Gawai and Pawar, 2006; Das and Baruah, 2006) which corroborates with the present findings.

The number of panicles /hill that is effective tillers/hill and 1000 grain weight are regarded as the selection criteria for adequate production of grain yield under the condition of submergence. These earlier findings of the scientist coincides the present findings. 
Table.1 Variations in number of inter nodes above $3 \mathrm{~cm}$, number of nodes with adventitious roots and survival \% in response to submerged condition of rice varieties

\begin{tabular}{|l|c|c|c|}
\hline Variety & $\begin{array}{c}\text { No. of internodes } \\
\text { above } \mathbf{3} \mathbf{~ c m}\end{array}$ & $\begin{array}{c}\text { No. of Nodes with } \\
\text { adventitious } \\
\text { roots }\end{array}$ & Survival \% \\
\hline Sarala & 5.98 & 3.28 & 63.1 \\
\hline Hanseswari & 6.61 & 3.76 & 68.82 \\
\hline Varshadhan & 6.85 & 4.23 & 71.33 \\
\hline Bankoi & 4.12 & 2.98 & 54.27 \\
\hline Champa & 4.10 & 2.93 & 58.82 \\
\hline CR-925-2 & 4.50 & 3.11 & 60.26 \\
\hline Mean & 5.36 & 3.38 & 62.76 \\
\hline SEm ( $)$ & 0.17 & 0.04 & 1.38 \\
C.D 5 \% & 0.53 & 0.14 & 4.08 \\
C.V & 4.79 & 2.38 & 3.43 \\
\hline
\end{tabular}

Table.2 Variation in plant height, number of tillers / hill, number of effective tillers/hill in response to submerged condition of rice varieties

\begin{tabular}{|c|c|c|c|c|c|c|}
\hline \multirow[t]{2}{*}{ Variety } & \multicolumn{2}{|c|}{ Plant height (cm) } & \multicolumn{2}{|c|}{ No. of tillers/hill } & \multirow{2}{*}{$\begin{array}{c}\text { No. of } \\
\text { effective } \\
\text { tillers/hill }\end{array}$} & \multirow{2}{*}{$\begin{array}{c}\text { \% of effective } \\
\text { tillers/hill }\end{array}$} \\
\hline & $\begin{array}{c}\text { Before } \\
\text { Submergence }\end{array}$ & $\begin{array}{c}\text { After } \\
\text { Submergence }\end{array}$ & $\begin{array}{l}\text { At } 90 \\
\text { Days }\end{array}$ & $\begin{array}{l}\text { At120 } \\
\text { Days }\end{array}$ & & \\
\hline Sarala & 114.80 & $\begin{array}{l}137.56 \\
(19 \%)\end{array}$ & 8.54 & $\begin{array}{c}8.00 \\
(-6.23 \%)\end{array}$ & 7.2 & 90.0 \\
\hline Hanseswari & 132.56 & $\begin{array}{c}150.80 \\
(13.75 \%)\end{array}$ & 9.53 & $\begin{array}{c}9.10 \\
(-4.5 \%)\end{array}$ & 8.40 & 92.3 \\
\hline Varshadhan & 135.53 & $\begin{array}{l}152.33 \\
(24 \%)\end{array}$ & 9.50 & $\begin{array}{c}9.20 \\
(-3.15 \%)\end{array}$ & 8.74 & 95.0 \\
\hline Bankoi & 110.93 & $\begin{array}{l}139.69 \\
(26 \%)\end{array}$ & 8.82 & $\begin{array}{c}8.03 \\
(-8.95 \%)\end{array}$ & 6.63 & 82.5 \\
\hline Champa & 108.06 & $\begin{array}{l}135.07 \\
(25 \%)\end{array}$ & 8.86 & $\begin{array}{c}8.20 \\
(-7.44 \%)\end{array}$ & 6.86 & 83.0 \\
\hline CR-925-2 & 112.33 & $\begin{array}{c}137.40 \\
(22.31 \%) \\
\end{array}$ & 9.06 & $\begin{array}{c}8.46 \\
(-6.62 \%)\end{array}$ & 7.10 & 84.0 \\
\hline Mean & 119.035 & 142.14 & 9.05 & 8.50 & 7.46 & 87.30 \\
\hline $\begin{array}{l}\text { SEm ( } \pm) \\
\text { C.D } 5 \% \\
\text { C.V }\end{array}$ & $\begin{array}{l}0.83 \\
2.63 \\
1.18 \\
\end{array}$ & $\begin{array}{l}1.13 \\
3.55 \\
1.37\end{array}$ & $\begin{array}{l}0.08 \\
0.26 \\
1.62\end{array}$ & $\begin{array}{l}0.07 \\
0.22 \\
1.53\end{array}$ & $\begin{array}{l}0.08 \\
0.25 \\
1.84\end{array}$ & \\
\hline
\end{tabular}


Table.3 Variation in Leaf area index (LAI), Specific leaf area (SLA) and Specific leaf weight (SLW) in response to submerged condition of rice varieties

\begin{tabular}{|l|c|c|c|}
\hline Variety & LAI & $\begin{array}{c}\text { SLA } \\
\left(\mathbf{c m}^{\mathbf{2} / \mathbf{g})}\right.\end{array}$ & $\begin{array}{c}\text { SLW } \\
\left(\mathbf{m g} / \mathbf{c m}^{\mathbf{2}}\right)\end{array}$ \\
\hline Sarala & 3.91 & 167.65 & 4.29 \\
\hline Hanseswari & 4.75 & 165.53 & 4.10 \\
\hline Varshadhan & 4.91 & 139.61 & 3.89 \\
\hline Bankoi & 3.32 & 212.74 & 4.48 \\
\hline Champa & 3.70 & 182.42 & 4.40 \\
\hline CR-925-2 & 3.85 & 176.39 & 4.39 \\
\hline Mean & 4.07 & 174.06 & 4.25 \\
\hline SEm ( $\mathbf{n})$ & 0.31 & 0.33 & 0.02 \\
C.D 5 \% & 0.99 & 1.05 & 0.08 \\
C.V & 9.53 & 0.33 & 1.07 \\
\hline
\end{tabular}

Table.4 Variation in Leaf area ratio (LAR), relative growth rate (RGR)and leaf weight ratio (LWR) in response to submerged condition of rice varieties

\begin{tabular}{|l|c|c|c|}
\hline Variety & LAR $\mathbf{~ c m}^{\mathbf{2}} / \mathbf{g}$ & RGR mg/g/day & LWR g/g \\
\hline Sarala & 52.20 & 37.33 & 0.28 \\
\hline Hanseswari & 56.96 & 37.36 & 0.27 \\
\hline Varshadhan & 58.78 & 38.93 & 0.30 \\
\hline Bankoi & 43.35 & 32.40 & 0.22 \\
\hline Champa & 46.06 & 34.30 & 0.23 \\
\hline CR-925-2 & 44.90 & 36.13 & 0.25 \\
\hline Mean & 50.37 & 36.07 & 0.26 \\
\hline SEm ( $\mathbf{n})$ & 0.42 & 0.58 & 0.06 \\
C.D 5 \% & 1.35 & 0.64 & 0.20 \\
C.V & 1.48 & 0.29 & 3.9 \\
\hline
\end{tabular}

Table.5 Variation in Crop Growth Rate (CGR), Net Assimilation Rate (NAR), leaf area duration (LAD) in response to submerged condition of rice varieties

\begin{tabular}{|c|c|c|c|}
\hline Variety & CGR mg/m²/day & NAR mg/dm $/$ day & LAD (in days) \\
\hline Sarala & 9.83 & 38.86 & 123.60 \\
\hline Hanseswari & 11.56 & 39.77 & 128.30 \\
\hline Varshadhan & 11.66 & 40.95 & 131.70 \\
\hline Bankoi & 8.15 & 34.40 & 114.50 \\
\hline Champa & 8.35 & 35.31 & 118.26 \\
\hline CR-925-2 & 8.86 & 36.70 & 119.80 \\
\hline Mean & 9.74 & 37.66 & 122.69 \\
\hline $\operatorname{SEm}( \pm)$ & 0.17 & 0.35 & 0.20 \\
\hline C.D $5 \%$ & 0.53 & 1.11 & 0.64 \\
\hline C.V & 3.02 & 1.63 & 0.29 \\
\hline
\end{tabular}


Table.6 Variation in partitioning of shoot dry matter (DM) at harvest in response to submerged condition of rice varieties

\begin{tabular}{|c|c|c|c|c|}
\hline Variety & $\begin{array}{c}\text { Stem(DM) } \\
\mathbf{g} / \mathbf{m}^{2}\end{array}$ & $\begin{array}{c}\text { leaf(DM) } \\
\mathrm{g} / \mathrm{m}^{2}\end{array}$ & $\begin{array}{c}\text { panicle(DM) } \\
\mathrm{g} / \mathrm{m}^{2}\end{array}$ & $\begin{array}{c}\operatorname{shoot(DM)} \\
\mathrm{g} / \mathrm{m}^{2}\end{array}$ \\
\hline Sarala & $\begin{array}{c}352.7 \\
(34.3 \%)\end{array}$ & $\begin{array}{c}209.7 \\
(20.4 \%)\end{array}$ & $\begin{array}{c}464.0 \\
(45.3 \%)\end{array}$ & 1024.4 \\
\hline Hanseswari & $\begin{array}{c}374.7 \\
(33.4 \%)\end{array}$ & $\begin{array}{l}168.3 \\
(15 \%)\end{array}$ & $\begin{array}{c}579.3 \\
(51.6 \%)\end{array}$ & 1122.3 \\
\hline Varshadhan & $\begin{array}{c}409.0 \\
(35.7 \%)\end{array}$ & $\begin{array}{l}227.3 \\
(20 \%)\end{array}$ & $\begin{array}{c}508.7 \\
(44.3 \%)\end{array}$ & 1145.0 \\
\hline Bankoi & $\begin{array}{c}304.3 \\
(32.9 \%)\end{array}$ & $\begin{array}{c}170.0 \\
(18.4 \%)\end{array}$ & $\begin{array}{c}451.0 \\
(48.7 \%)\end{array}$ & 925.3 \\
\hline Champa & $\begin{array}{c}362.7 \\
(37.26 \%)\end{array}$ & $\begin{array}{c}173.7 \\
(17.84 \%)\end{array}$ & $\begin{array}{c}436.7 \\
(44.9 \%)\end{array}$ & 973.3 \\
\hline CR-925-2 & $\begin{array}{c}399.7 \\
(39.01 \%)\end{array}$ & $\begin{array}{c}189.0 \\
(18.43 \%)\end{array}$ & $\begin{array}{c}436.3 \\
(42.56 \%)\end{array}$ & 1025.0 \\
\hline Mean & 367.2 & 189.7 & 479.3 & 1041.0 \\
\hline $\operatorname{SEm}( \pm)$ & 3.2 & 1.6 & 4.4 & 9.1 \\
\hline C.D $5 \%$ & 10.1 & 4.9 & 13.9 & 28.7 \\
\hline C.V & 1.51 & 1.42 & 1.59 & 1.52 \\
\hline
\end{tabular}

Table.7 Variation in panicle length, grains/panicle, ripened grain/panicle, \% of ripen grain/panicle, chaffy grain/panicle, $\%$ of chaffy grain/panicle in response to submerged condition of rice varieties

\begin{tabular}{|c|c|c|c|c|c|c|}
\hline Variety & $\begin{array}{c}\text { Panicle } \\
\text { length } \\
\text { (cm) }\end{array}$ & $\begin{array}{c}\text { No. of Grains/ } \\
\text { Panicle }\end{array}$ & $\begin{array}{c}\text { No. of } \\
\text { ripened } \\
\text { grain/ } \\
\text { panicle }\end{array}$ & $\begin{array}{c}\text { \% of } \\
\text { ripened } \\
\text { grain/ } \\
\text { panicle }\end{array}$ & $\begin{array}{c}\text { No. of } \\
\text { chaffy } \\
\text { grain/ } \\
\text { panicle }\end{array}$ & $\begin{array}{c}\text { \% of } \\
\text { chaffy } \\
\text { grain/ } \\
\text { Panicle }\end{array}$ \\
\hline Sarala & 24.90 & 198.53 & 164.66 & 84.03 & 31.66 & 15.90 \\
\hline Hanseswari & 25.83 & 225.96 & 185.33 & 81.60 & 42.66 & 18.30 \\
\hline Varshadhan & 27.36 & 232.33 & 203.33 & 91.56 & 17.00 & 8.33 \\
\hline Bankoi & 24.80 & 201.60 & 172.00 & 81.13 & 38.00 & 18.76 \\
\hline Champa & 25.03 & 187.15 & 159.33 & 85.56 & 27.00 & 14.33 \\
\hline CR-925-2 & 25.30 & 209.66 & 173.66 & 85.03 & 31.33 & 14.86 \\
\hline Mean & 25.53 & 209.20 & 176.38 & 84.82 & 31.27 & 15.08 \\
\hline SEm ( $\mathbf{n}$ & 0.25 & 2.23 & 1.70 & 1.10 & 2.47 & 1.10 \\
C.D 5 \% & 0.79 & 7.03 & 5.37 & 3.47 & 7.80 & 3.49 \\
C.V & 1.70 & 1.85 & 1.67 & 2.25 & 13.72 & 12.72 \\
\hline
\end{tabular}


Table.8 Variation in 1000 grain weight, grain yield, harvest index (HI) in response to submerged condition of rice varieties

\begin{tabular}{|l|c|c|c|}
\hline Variety & 1000 grain weight $(\mathrm{g})$ & grain yield $(\mathrm{q} / \mathrm{ha})$ & Harvest index $(\mathrm{HI})$ \\
\hline Sarala & 19.26 & 35.43 & 35.03 \\
\hline Hanseswari & 21.46 & 41.53 & 36.24 \\
\hline Varshadhan & 24.58 & 41.73 & 36.97 \\
\hline Bankoi & 23.27 & 28.70 & 27.76 \\
\hline Champa & 20.95 & 29.76 & 28.96 \\
\hline CR-925-2 & 18.20 & 32.36 & 34.50 \\
\hline Mean & 21.28 & 34.92 & 33.24 \\
\hline SEm $\mathbf{( \pm )}$ & 0.02 & 0.23 & 0.67 \\
C.D 5 \% & 0.06 & 0.74 & 2.11 \\
C.V & 0.15 & 1.18 & 3.49 \\
\hline
\end{tabular}

On the contrary lower values of these above yield attributing parameters reduced the yield on Bankoi. Size of of the grain measured in terms of 1000 grain weight which was maximum in Varsadhan (24.58gm). The high yield was due to translocation of carbohydrate from the stem and leaf after regeneration and also accompanied with more dry biomass production after submergence (Islam and Peng, 2010). Partitioning of photosynthates into grains as measured in terms of harvest index (HI) showed maximum value (36.97\%) in Varsadhan followed by Hanseswari (36.24\%) which was significantly greater than the intolerant cultivar Bankoi (27.76\%). Grain yield is significantly related with harvest index (HI) in rice crop (Yan et al., 2010; Fageria, 2007 and Li et al., 2012). Varietals difference in yield in respect of the harvest index (HI) is considered as a selection criteria for yield component which has already been documented and reviewed earlier ( $\mathrm{Li}$ et al., 2012). The present findings corroborate the finding of earlier workers. The 1000 grain weight may affect rice yield in some extent, but rarely become limiting under most condition. Therefore under present investigation important should be given on number of effective tills/hill and number of filled up grains/panicle, dry matter accumulation, nitrogen uptake after the submergence to increase the yield potential of rice genotypes (Li et al., 2012).

In conclusion, the present study suggested significant variations among rice varieties for morpho-physiological traits under water logged and submerged condition. In the present study it may be concluded that among the varieties Varsadhan contributed highest yield due to it tolerance under water logged and submerged condition.

\section{References}

Baloch, M.S., Anayanta, U.A. and Gul, H. 2006. Growth and yield of rice affected by transplants dates under high temperature of Dera Ismal Pakistan, Publish online.

Baruha, K.K., Rajkhowa, S.C. and Dash, K. 2006. Physiological analysis of growth, yield development and grain quality of some deep water rice cultivars. J. Agronomy and Crop Sci., 192(3): 228-232.

Brown, R.H. 1984. In: M. B. Teasar (Ed), Growth of the green plant, Physiological Basis of Crop Growth and Development, ASA, CSSA, Madison, Wisconsin, USA, pp.153173.

Catling, H.D. 1985. An Agro-Ecological Characterization of the Deep Water Areas in the Chao Phya Basin of Thailand with a Subdivision into Five Regions. International Rice Research Institute, Los Banos, The Philippines.

Chattha, T.M. and Khan, M.A. 1991. Study on relationship between physiological parameters of indices. Pakistan J. Scientific and Industrial Res., 4(1): 37-39.

Chen, H.J. and Wang, S.J. 2008. Molecular regulation of sink source transition in rice leaf sheath during heading period. Acta Physiol. Plant, 30: 639-649. 
Dalmia, A. and Sawhney, V. 2004. Anti oxidant defence mechanism under drought stress in Wheat seedling. Physiol. Mol. Biol. Plant. 10(1):109-114.

Das, K. and Baruah, K.K. 2007. A comparison of growth and photosynthetic character of two improved cultivar from methane emission rainfed agro-ecosystem of North East India.Department of crop Physiology, Assam Agri. University, Jorhat online information 30:10.

Fageria, N.K. 2007. Yield physiology of rice. $J$. Plant Nutrition. 30:843-879.

Fridman, E. and Zamir D. 2003. Functional divergence of a synthetic invertase gene family in tomato, potato and Arabidopsis. Plant Physiol., 131: 603-609.

Gawai, P.P and Pawar, V.S. 2006. Integrated nutrient management in sorghum (Sorghum bicolor)- chickpea (Cicer arietinum) cropping sequence under irrigated conditions. Indian J. Agron., 51: 17-20.

Ghosh, A. 2000. Developing efficient nitrogen management in rainfed rice production system under flood-prone and water logged situation. Fert. News, 45(8): 59-60.

Islam, M.S. and Peng, S. 2010. Comparative study on yield and yield attributes of hybrids and NPT rice genotypes in a tropical irrigated ecosystem, Bangladesh J. Agril. Res., 35(2): 343-353.

Li, X., Yan, W., Agrama, H., Jia, L. and Jackson, A. 2012. Unraveling the Complex Trait of Harvest Index with Association Mapping in Rice (Oryza sativa L.. PLoS One, 7(1): 29350.

Murty, K.S. and Pattnaik, R.K. 1986. Net assimilation rate of traditional rice varieties at vegetative growth stage. Oryza, 23(1): 45-49.

Nasiruddin, M., Ahmed, M.S., Zaman, S.M.H. and E. Haq. 1977. Effects of flooding on morphological characteristics of floating rice varieties of Bangladesh. In Proceedings of the 1976 Deepwater Rice Workshop, Bangkok, Thailand. International Rice Research Institute, Manila.67-74.

Oerke, E.C.C., Weber, A., Dehne, W.H. and Schonbeck, F. 1999.Crop Production and crop protection: Elsevier, Amsterdam.

Panse, V. G. and Sukhatme, P. V. 1961. Statistical methods for agricultural workers. 2nd Edn ICAR, New Delhi, 361.

Paroda R.S. 2006. Strategy for increasing productivity growth rate in agriculture.PIB Government of India online information, 30: 11 .

Perata, P. and Voesenek, L.A.C.J. 2007. Submergence tolerance in rice requires Sub1A, an ethylene-response-factor-like gene. Trends Plant Sci., 12: 43-46.

Sarkar, R.K., Reddy, J.N., Sharma, S.G., and Ismail, A.M. 2006. Physiological basis of submergence tolerance in rice and implications for crop improvement. Curr. Sci., 91(7): 899-906.

Sugawara, T. and T. Horikawa. 1971. Studies on elongation of internodes in floating rice plants - morphological and histological observation [in Japanese, with English summary] Bull. Coll. Agric Utsumomiya Uni. 8(1): 25-46.

Watson, D.J. 1958. Leaf growth in relation to crop yield - the growth of leaves. Mithorpe (ed.) Butter worths, London.

Yan, C., Ding, Y., Wang, Q., Liu, Z., Li, G., Muhammad, I. and Wang, S. 2010.The impact of relative humidity, genotypes and fertilizer application rates on panicle, leaf temperature, fertility and seed setting of rice. J Agric Sci., 148: 329-339.

Yoshida, S. (1981). Fundamentals of rice crop science, International Rice Research Institute, Philippines.

\section{How to cite this article:}

Padhiary, A.K., B. Hota, B. Kar, S. Rout, P.K. Behera and Patra, S.S. 2017. MorphoPhysiological Traits of Different Rice Varieties Grown Under Water Logged and Submerged Condition. Int.J.Curr.Microbiol.App.Sci. 6(2): 202-214.

doi: http://dx.doi.org/10.20546/ijcmas.2017.602.027 